\title{
Hypotension in the high-dependency unit: a conundrum
}

\author{
Malik Muhammad Fareed Ali Janjua, ${ }^{1}$ Sunil John, ${ }^{1}$ Kishore Sieunarine, ${ }^{2}$ \\ Venkata Kodali ${ }^{1}$
}

${ }^{1}$ Department of Medicine, Geraldton Regional Hospital, Geraldton, Western Australia, Australia

${ }^{2}$ Department of Vascular Surgery, West Coast Vascular, Nedlands, Western Australia, Australia

Correspondence to Dr Venkata Kodali, venkatkodali@hotmail.com

Accepted 7 June 2014

\section{(a) CrossMark}

To cite: Janjua MMFA John $\mathrm{S}$, Sieunarine K, et al. BMJ Case Rep Published online: [please include Day Month Year] doi:10.1136/ bcr-2014-205267

\section{DESCRIPTION}

A 62-year-old man was admitted with dizziness while walking on the beach. He had significant headaches and cough and phlegm for a week. In the hospital he had shortness of breath and dizziness on walking to the toilet and back. The patient's medical history included chemotherapy and radiation to the neck for Hodgkin's lymphoma with no recurrence. Clinical assessment showed hypotension in the upper limbs and right carotid bruit. Initial treatment included intravenous antibiotics and aggressive fluid management. A CT pulmonary angiogram excluded pulmonary embolus. Clinically he looked well with good urine output. Blood pressure in the legs was normal. Bilateral upper limb occlusive disease was suspected which was confirmed on arch aortogram (figure 1). This showed a complete occlusion of left subclavian, patent right and left common carotid with occlusion of right and left external carotid arteries and preocclusive lesion at origin of the right subclavian artery. He underwent successful right subclavian angioplasty with symptomatic improvement.

Investigations for arteritis and lipid profile were normal. We suspect radiotherapy in addition to smoking and diabetes contributed to the current occlusions.

Unilateral subclavian stenosis is a common site for upper limb arterial disease. Bilateral subclavian stenoses is very rare with less than 10 cases in the English literature. ${ }^{1}{ }^{2}$ With occlusion of the subclavian arteries, there is reverse flow in the right and left vertebral, stealing blood from the Circle of Willis resulting in symptoms of dizziness.

\section{Learning points}

- Low blood pressure in both arms should prompt checking the lower legs especially when a patient has normal urine output.

- Radiotherapy can induce arteritis and vascular occlusions.

\section{Competing interests None.}

Patient consent Obtained.

Provenance and peer review Not commissioned; externally peer reviewed.

\section{REFERENCES}

1 Dayama A, Riesenman PJ, Cheek RA, et al. Endovascular management of aortic arch vessel occlusion: successful revascularization of innominate and left subclavian arteries. Vasc Endovascular Surg 2012;46:273-6.

2 Ghetie D, Rudinskaya A, Dietzek A. Polymyalgia rheumatica with bilateral subclavian artery stenosis. Am J Med 2010;123:e1-2.
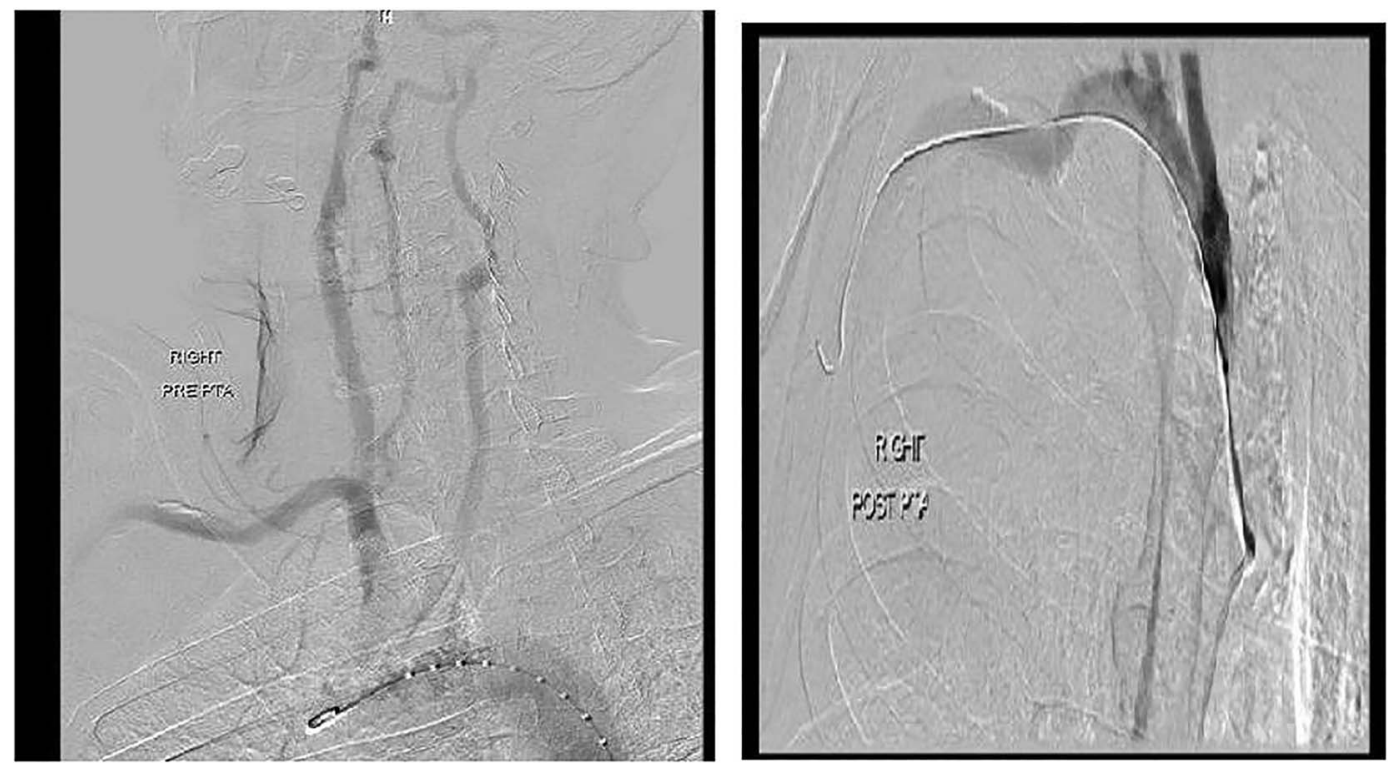

Figure 1 Arch aortogram showing bilateral occlusion of subclavian arteries. 
Copyright 2014 BMJ Publishing Group. All rights reserved. For permission to reuse any of this content visit http://group.bmj.com/group/rights-licensing/permissions.

BMJ Case Report Fellows may re-use this article for personal use and teaching without any further permission.

Become a Fellow of BMJ Case Reports today and you can:

- Submit as many cases as you like

- Enjoy fast sympathetic peer review and rapid publication of accepted articles

- Access all the published articles

- Re-use any of the published material for personal use and teaching without further permission

For information on Institutional Fellowships contact consortiasales@bmjgroup.com

Visit casereports.bmj.com for more articles like this and to become a Fellow 